Reseñas

\title{
Laughlin, Robert, 2002, La gran serpiente cornuda. Indios de Chiapas, no escuchen a Napoleón, Programa de Investigaciones Multidisciplinarias sobre Mesoamérica y el Sureste, UNAM, México.
}

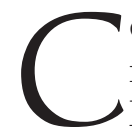
on este sugerente título, Robert Laughlin nos introduce en un documento que resulta singufirmada en 1812 por el Duque del Infantado y dirigida a los habitantes de ultramar con la orden de ser traducida a las lenguas nativas. Con ella se convoca a los pueblos indígenas a mantener la lealtad a la Madre Patria y a no dejarse seducir por las fuerzas de Napoleón, quien ocupaba tierras españolas y era la imagen misma del mal y la traición, por lo que se le personificaba, entre otras cosas, como a una "serpiente cornuda". Más allá de lo interesante que resulta el análisis de un documento como la proclama mencionada, lo que desde mi punto de vista el autor ofrece es lo que ha sido, después de la Conquista y a lo largo de nuestra historia, el encuentro con "el otro": el indígena con el español.

Si su quehacer como antropólogo y su conocimiento de la lengua permitieron a Rober Laughlin (autor del Diccionario Tzotzil de Zinacantán publicado por el Smithsonian Institute en 1975) realizar un magnífico análisis y sacar de este singular documento todo el jugo posible, su enorme sentido del humor hizo que este libro, además de ser interesante para académicos y especialistas orientados al estudio de las relaciones entre México y España en aquel momento de la historia, fuera también fascinante y divertido; el autor nos permite participar en la sorpresas que le causan sus descubrimientos y las numerosas citas en ningún momento hacen que el texto sea farragoso, pues Laughlin va entretejiendo detalles de todo tipo que completan el panorama. Así encontramos datos sobre las preocupaciones de las autoridades, los tormentos de los diputados, las infidelidades de los integrantes de las Cortes de Cádiz o las debilidades del "Príncipe de la Paz", Manuel de Godoy y Álvarez de Faria. También hay información sobre Chiapas, ya sea sobre la rebelión indígena en Chamula, durante el siglo XVIII, o sobre la compra, por parte de la elite de San Cristóbal, de la mayor parte del área norte para establecer fincas cafetaleras y ranchos ganaderos en el siglo XIX, o sobre la manera en que Victórico Grajales ordenó la quema de santos en las plazas de cada pueblo y prohibió el habla de las lenguas indígenas; y por supuesto, se habla también sobre la rebelión zapatista. Diversos son los episodios de este recuento de horrores con los que han violados los derechos humanos de los indígenas, tanto por acción como por omisión.

El libro mantiene a los lectores en permanente estado de seducción al presentar, como dice Robert Laughlin, este "teatro del absurdo" por medio del cual podemos, entre otras cosas, observar con claridad la forma en que España veía a los habitantes indígenas de ultramar y, por otra parte, las enormes similitudes en el ejercicio de la política y sus estrategias en aquel tiempo y en la actualidad, a pesar de que nos separan muchos 
años. La lectura del texto genera claridad acerca de la forma en que, durante La Colonia, se dio el encuentro con el "otro" y, al mismo tiempo, genera múltiples interrogantes sobre la política indigenista de hoy y sobre los cambios (o ausencia de ellos) que han tenido lugar en el encuentro con el "otro".

Localizar el documento fue el principio de la aventura que inició Robert Laughlin en 1980. Una versión mecanografiada de la Proclama de 1812 había sido donada al Smithsonian Institute en 1930 por el Bureau of American Ethnology. Cuando llegó a manos de Laughlin, él puso manos a la obra para buscar el original; se fue a España con su familia y pasó por bibliotecas y hemerotecas sin encontrarlo. Posteriormente estableció contacto con los descendientes del Duque del Infantado con la esperanza de que, por haber firmado éste el documento, ellos conservaran un ejemplar. Al hurgar en estos papeles, Robert Laughlin sólo encontró varias menciones de la Proclama y corroboró que había sido elaborado por De Mosquera. Y ni Laughlin mismo supo con certeza qué lo llevó a regresar una vez más a la Biblioteca del Congreso, tomar un libro al azar y encontrar finalmente el documento. Únicamente le faltaba la traducción al tzotzil; fue en los archivos episcopales de San Cristóbal de Las Casas, a su regreso a Chiapas, donde entre bancas rotas, púlpitos abandonados y estantes llenos de tomos antiguos, en un segundo piso al que subió a escondidas para mirar por el ojo de la cerradura, su búsqueda quedó completa al haber encontrado la traducción.

Para hablar de la proclama, Robert Laughlin comienza haciendo un planteamiento sobre el momento que vivía España y todos los enredos entre Carlos IV, el Príncipe de la Paz, María Luisa de Parma y su retoño Fernando, quien finalmente inició su gobierno como "El Deseado", para convertirse tiempo después en "Pepe Botella". Fueron momentos de grandes intrigas, pues con la invasión al territorio español, Napoleón había provocado el nacimiento de las guerrillas y la guerra de resistencia. Continúa el planteamiento con la descripción de Cádiz, puerto comercial amurallado, donde se reunieron españoles y representantes del Nuevo Mundo para elaborar una nueva Constitución. Así, el autor nos habla de los efectos políticos y sociales que tuvo la Constitución de Cádiz de este lado del océano, en Perú, Guatemala y por supuesto México. Sin embargo, a pesar de que "el león tenía al águila francesa entre los dientes", existía el temor por el futuro de España y de sus colonias, y se veía la necesidad de alertar a los habitantes del reino con el fin de conservar la soberanía nacional y evitar que se generara el apoyo para el "Luzbel" Napoleón, quien curiosamente alentaba a las colonias a buscar su independencia. Una vez con el panorama completo, Laughlin aborda la proclama, producto de un movimiento patriótico alentado por la visión de un liberalismo político y económico al que, además, se sumó un nacionalismo romántico. Por último, el autor analiza la traducción de la proclama, sin dejar de preguntarse sobre la identidad del traductor, posiblemente un fraile que agregó, de su ronco pecho, cuanta imagen creyó conveniente.

La proclama, aunque firmada por el Duque del Infantado, fue elaborada por Joaquín De Mosquera y Figueroa, patriota colombiano que antes de llegar a la regencia había desempeñado varios cargos en el Virreinato de la Nueva España y había actuado como visitador en Caracas. De Mosquera tenía un puesto importante en la regencia y cuando el Duque salía a combates él se quedaba al frente de ésta. Antes de la proclama de 1812, De Mosquera ya había acudido a la estrategia de las cartas a los súbditos que vivían del otro lado del océano, ya para recordarles que, junto con los españoles, formaban una misma familia, ya para convocarlos a que "renazcan las dulces ideas de la fraternidad y la unión”, o para que volvieran los ojos a la "Madre Patria que no os echará en olvido", o bien para solicitar venganza contra Napoleón, el "déspota más furioso y vengativo". Pero ninguna de las misivas tuvo la distinción de llegar a América con la instrucción específica de ser traducida e impresa en las lenguas del reino. En la proclama, el Duque del Infantado, regente de las cortes, pide a los indígenas lealtad y, 
a cambio, prometía no sólo prosperidad, sino felicidad. La Proclama de 1812 fue traducida en Huitiupán posiblemente, considera el autor, por un fraile que agregó de su propia cosecha un vocabulario apocalíptico y la llenó de imágenes del Antiguo Testamento. La traducción es una mezcla de tzeltal y tzotzil, posiblemente porque el lugar donde se realizó, norte de Chiapas, era paso para muchos indígenas de ambas etnias y se pretendía que todos pudieran entender la proclama.

Entre los agregados aparece precisamente la imagen de Napoleón, que da título al libro, como una "serpiente cornuda", con el fin de representar toda la maldad de este "codicioso monstruo (...) imagen de la traición y el engaño". Sin embargo, el traductor no consideró demasiado lo que podría o no significar el término localmente, o confió en que los trescientos años de conquista hubieran cambiado el significado de los símbolos. Como para cualquier español, la serpiente tenía un signo negativo y producía un temor mítico. En el País Vasco se la representaba dormida en las oquedades de los Pirineos y, como en el resto de Europa, aparecía siempre junto a la culebra y el dragón en todos los bestiarios imaginados. Pero además el traductor agregó unos cuernos, asociados con el diablo, de acuerdo con el pensamiento judeocristiano. Cabe considerar que esta imagen no tuviera la misma significación para los indígenas mesoamericanos, quienes habían reverenciado durante varios siglos a la serpiente cubierta de plumas como símbolo de vida y divinidad. Esta representación aparece en el tiempo de los olmecas junto con la imagen del maíz. La sabiduría que se le atribuye recuerda incluso al dios griego del conocimiento. Y sobre los cuernos, a pesar de que la referencia no es tan clara, Laughlin menciona que en algún momento apareció en el mundo maya este dios-serpiente, Kukulkan, con cuernos, posiblemente - agrega - como la fusión de un mito ancestral maya con otro con significación no de maldad, sino de combate, llegado desde el "viejo continente", amalgamado a su vez con tradiciones no cristianas mucho más antiguas. No podemos olvidar que los cuernos también remitían (y aún lo hacen) a ese animal fabuloso que es el toro, símbolo fálico de la fecundidad masculina y de la fuerza (por algo Dionisio, Alejandro Magno e incluso Moisés aparecen portando toros); los cuernos estaban presentes en el altar de los sacrificios del pueblo israelí y son amuleto e imagen de la abundancia.

El libro trata, como dice el autor, de una "divertida pero triste historia de la mirada política que el gobierno tiene sobre los indígenas desde hace ya 200 años", que nos ayuda a explicar la conquista después de La Conquista, algunos de sus métodos, de sus estrategias, de su mirada, y cómo aún hoy permanecen vigentes.

Parece absurdo que los indígenas pudieran estar interesados en las preocupaciones que atormentaban a los diputados en las Cortes de Cádiz; en este mundo tan distante no sólo geográficamente, sino simbólicamente, de la vida y de los afanes indígenas. Pero causa especial extrañeza y curiosidad pensar, en el caso de que realmente se haya leído la proclama (pues de eso no se tiene certeza), la reacción y la forma de percibir todas las imágenes que ahí se encuentran y que hablan de Napoleón como un engañador, un anticristo que declara ser dueño del Universo, como la revelación de las fuerzas del mal, como el demonio dirigido por Satán, como un dragón, mientras que a Fernando VII se le reconoce como el sustituto de Dios en la tierra, el Salvador heroico que ama y protege a sus "hijos los indios". La mirada española, con sus intenciones y su verbo manipulador, generó un discurso apto posiblemente para campesinos españoles, en el que se encontraba algo de lo que los criollos querían escuchar y las autoridades eclesiásticas promover, pero nada que realmente tuviera que ver con lo que los indígenas pudieran añorar.

La proclama implica el reconocimiento de algunos hechos y el desconocimiento de otros. Hay, en principio, claridad acerca del fracaso de un proyecto educativo que hubiera permitido a los indígenas, después de rescientos años, conocer el español. Paralelamente, permanece la certidumbre de que las lenguas indígenas continúan en uso permanente en una gran parte del país. Hay un 
reconocimiento también de que la elite indígena no era un camino de comunicación con el resto de sus congéneres pues, como dice J. P. Sartre: "se les había marcado con hierro candente los principios de la cultura occidental, eran mentiras vivientes que no tenían nada que decir a sus hermanos" (en el prólogo al libro de Franz Fanon, Los condenados de la tierra). La proclama de 1812 evidenciaba también el desconocimiento de lo que se vivía en los pueblos indígenas, pues parece absurda la simple propuesta de que los indígenas pudieran estar interesados en los conflictos de los europeos y en tomar partido por alguno de ellos. Este último punto posiblemente no es tan absurdo si consideramos que, a pesar de la distancia con la corona y sus quehaceres, el temor estribaba en que el Capitán General de la Provincia de Guatemala "y su compañero del alma el arzobispo", representantes de la oligarquía y sumamente conservadores, pudieran tener una influencia en las localidades.

Respecto al tono de la proclama, independientemente del florido lenguaje que la adorna hay, por supuesto, una amenaza velada; pero es principalmente una proclama benevolente y predomina la idea de protección a los súbditos y una oferta descabellada que ofrece prosperidad y "felicidad" para los pueblos indios.

Lo curioso es que, a lo largo del texto, irremediable y continuamente viene a la mente la similitud entre esta Proclama de 1812 con el acontecer político de la actualidad. La misma relación: una enorme distancia cultural entre unos marginados e indígenas y otros, poderosos y educados en los principios de la cultura occidental. Similar situación de hambre y pobreza, y los mismos protagonistas: el Gobernador, el Obispo, la autoridad eclesiástica más conservadora, los líderes militares y los diputados son los que toman las decisiones. Las estrategias también son las mismas: el equilibrio entre amenaza y promesa que aún hoy se repiten desde el poder, todos los días, ya sea desde el púlpito en los templos católicos, evangélicos o de cualquier denominación, en la escuela, en la casa y, por supuesto, en el ámbito político, tanto en tiempos de campaña como en la cotidianeidad de la vida. Cabe recordar que durante el conflicto zapatista el Gobierno se mostró dispuesto a castigar severamente a los indígenas que habían trastornado el orden público y, simultáneamente, a darles la oportunidad de entregarse al considerar que, sin ser malas personas, eran guiados por la ignorancia y el temor a cabecillas ajenos a sus intereses. El autor nos recuerda que esta mezcla de amenaza y promesa fue utilizada en Chamula en 1869, cuando el Gobierno mexicano emitió otra proclama en la que decía que: "los pueblos todos de Indios sublevados", se ofrecía el perdón si se entregaban y, en caso contrario, se les amenazaba con la muerte de ellos y sus familias: "si huyen padecerán y luego vendrá la muerte, si huyen no podrán cuidar sus sementeras y no tendrán que comer. Como lo que quieren es injusto todos los santos están enojados y por esos se cayó La Iglesia de Chamula. Los cabecillas están engañándolos. El presidente está enojado y dice va a mandar soldados para acabar con ustedes. Vengan y presenten sus armas". Esta proclama contrasta con el tono de benevolencia de la de 1812, pues la amenaza está mucho más velada, pero tiene mensajes extrañamente similares a los enviados, en la década de los noventa, al Ejército Zapatista.

También encontramos, en la Proclama de 1812, el mismo ánimo utilitario que sugiere promesas descabelladas e incumplibles, como el ofrecimiento de felicidad, caminos, hospitales, educación y abundantes cosechas que se olvidan una vez resuelto el conflicto o ganada la campaña. Como dice Robert Laughlin, era "un informe de gobierno excepto por la falta de estadísticas". Y si al principio fue necesario que corriera mucha sangre y la población indígena disminuyó tanto que hubo que traer negros para ayudar en los trabajos, para el momento de la Proclama de 1812 esta arrogancia se había convertido en manipulación abierta, en amenaza velada, en una recomendación de un superior a un inferior. Imponer una mirada no deja de ser una guerra.

Pero además de las promesas es necesario denostar al contrincante. Si Napoleón era una "serpiente cornuda", Felipe Calderón utilizó imágenes igualmente distorsio- 
nadas para combatir a López Obrador cuando, mientras uno abrazaba ancianos y besaba niños, el otro aparecía amenazante y desquiciado; la amenaza roja que nos llevaría al comunismo a ultranza. Persiste la creencia de que el futuro depende de una sola persona, ya sea de un malvado o de un salvador, como lo fue Fernando VII en su momento. También encontramos el mismo manejo de la información no para que el mundo indígena tuviera acceso a ella, sino para permitir la manipulación. La Proclama de 1812 es entonces, finalmente, una muestra de la antigua práctica de la manipulación política, presente incluso, durante la conquista en la alianza de españoles con tlaxcaltecas. Es el mismo conflicto donde los indígenas se encuentran atrapados entre la Iglesia, el Estado y su deseo de mantener una identidad propia.

Prevalece sobre todo la misma mirada de los europeos de aquel tiempo, convencidos de su superioridad frente a los indios. Dicha mirada se trasluce, como se puede ver en la proclama, como un trato a los indígenas como si fueran menores de edad o ignorantes. Y también es el mismo cogollo del conflicto. Igual ocurrió en 1812, en 1778 en Chamula y en 1994 en Los Altos, por nombrar tres momentos clave de la historia. Es una mirada que desconoce al "otro" y no tiene idea de con quién habla. Pero si la mirada proyectada al mundo americano desde España puede entenderse, la de quienes vivían cerca de los indios y compartían su lengua es más sorprendente. El responsable de la traducción, con su lenguaje florido, tampoco parece haber entendido nada sobre este otro mundo, y su proclama nos habla más de un personaje trasnochado, de una realidad de entonces y de ahora. El "otro", el indígena, no se conoce ni se reconoce. La distancia cultural con frecuencia parece insalvable. Eran (y siguen siendo) dos mundos que pertenecían a culturas y a tiempos distintos, y queda la impresión de que no encontraron puntos de contacto.

Es, en resumen, un libro que habla de la incapacidad y falta de interés por entender y respetar al "otro"; actitudes que permanecen en la Colonia después de trescientos años de convivencia y que está presente hoy, después de doscientos años de independencia y a pesar de que la población indígena suma varios millones de personas. Antes y ahora, en las relaciones que se sostienen, ya sea desde el poder central o los pequeños poderes locales, no hay la disposición a ver al "otro", sino de valerse de él, de utilizarlo, de imponerle una forma de ver. Una lamentable pérdida en todos los sentidos.

Kapuscinski, en su libro Encuentro con el otro, se pregunta sobre los caminos para poder acercarse a quien tiene otra fe, un sistema de valores distinto, diferentes costumbres y tradiciones y otra cultura. Estos encuentros, dice, permiten diversas reacciones, como abalanzarse con ferocidad, generar guerras y conflictos; también es posible pasar frente al "otro" con indiferencia, aislarse para evitar el contacto, pero finalmente cabe la posibilidad de intentar conocer y comprender al "otro" y dar lugar a esta experiencia básica y universal. Lamentablemente, desde La Conquista, durante La Colonia y hasta hoy en día, en México las relaciones entre el poder y los indígenas se han caracterizado por el etnocentrismo, por la convicción de la superioridad del europeo, quien abandonaba su tierra sólo por las ventajas de la conquista y el negocio, pero no para conocer a los habitantes de otras tierras. Son relaciones teñidas de arrogancia y desdén.

Hace quinientos años los españoles se preguntaban si los nativos de esta tierra tendrían alma, pero el posterior reconocimiento de "la humanidad del indígena" no modificó mucho su situación. Someter, colonizar y dominar son acciones que continúan repitiéndose a pesar que, desde La Ilustración, se reconoció que el individuo no blanco y no cristiano, "ese ser monstruoso que tanto difiere de nosotros", es también un ser humano.

Se ha escrito mucho sobre la necesidad de poner en pie de igualdad a todos los seres humanos, mucho se ha hablado de la tolerancia, pero las autoridades siguen actuando como lo hicieron los españoles en 1812 y eso, como dice Kapuscinski, habla del fracaso del ser humano por "su incapacidad de entenderse con los otros, de meterse en su piel, pone en tela de juicio su bondad y su inteligencia". 
Pero Kapuscinski agrega algo esperanzador. Aunque el proceso transcurre en medio de dificultades, día con día crece el número de comunidades que adquieren y acrecientan un sentimiento de su propio valor, de su importancia; aumenta la convicción para no permitir que se les trate como objeto. $\mathrm{Y}$, en medio de todo, lo que encontramos es la lucha entre la corriente moder- nizadora de uniformar la realidad; y la contraria, de preservar las diferencias.

Lourdes Herrasti Maciá

Egresada de la Maestría en Ciencias Sociales

y Humanísticas

CESMECA-UNICACH 